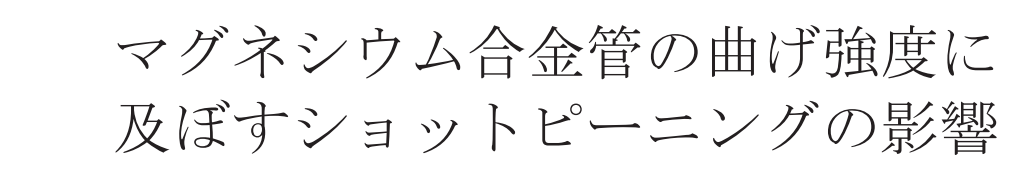

原田 泰典* 福田 泉** 山本 厚之*

\title{
Effect of Shot Peening on Bending Strength of Magnesium Alloy Pipe
}

\author{
Yasunori HARADA*, Izumi FUKUDA** and Atsushi YAMAMOTO*
}

(Received on July 9, 2014)

\begin{abstract}
This paper deals with the effect of shot peening on the bending strength of an AZ31 magnesium alloy pipe. Magnesium alloy has a wide range of application prospects in the automobile and electronic industries. AZ31 alloy is the most widely used commercial magnesium alloy. In our experiment, extruded pipes of $22 \mathrm{~mm}$ O.D., 18 mm I.D., and $2 \mathrm{~mm}$ wall thickness were used. Shot peening treatments were applied to the surface of the workpiece using an impeller-type or an air-type peening machine. Tensile and compressive tests were carried out under axial load at a crosshead speed of $10 \mathrm{~mm} / \mathrm{min}$, and bending strength tests were performed at a crosshead speed of $100 \mathrm{~mm} / \mathrm{min}$ under lateral load using an Instron-type testing machine. In the bending tests, the peened workpiece could withstand higher bending yield load. The surface layer of the peened workpieces was also observed by electron backscatter diffractometry (EBSD). It was found that multiple deformation twins were formed during shot peening. The results of the present study revealed that the compressive yield stress of shot-peened pipes is strongly related to their bending strength.
\end{abstract}

Key words: bending, material testing, magnesium alloy, pipe, shot peening, surface treatment, bending strength, tension test, compression test, deformation twin, EBSD.

\section{1. 緒 言}

省エネ社会の構築が求められている中, 軽量材料の一つ であるマグネシウム合金は構造用材料として利用範囲が急 速に広がっている. 携帯電話やラップトップパソコンなど の多くのモバイル機器, 電子デバイス用筐体などの製品と して実用化されている ${ }^{1)}$. とくに, 搬送機器業界では軽量 化の効果的な一つの方法として鉄鋼材料の一部を軽金属人 適用することが試みられている。このような背景から，こ れまでにマグネシウム合金の実用化に向けた多くの研究が 行われている. 疲労特性評価では疲労亀裂進展に及ぼす湿 度の影響や切欠き感受性の影響について ${ }^{2), 3)}$, また機械的 性質評価では常温での降伏曲面や鍛造温度の影響につい

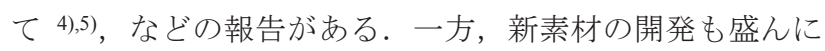
行われている。耐熱性や高強度を有する合金開発につい て ${ }^{6,7)}$, また材料強化の観点からは希土類元素を添加した 合金のような組成制御によって機械的性質の著しい強化を 図った研究について ${ }^{8)}$, などの報告がある.

マグネシウム合金を軽量構造材として適用拡大する上で

*兵庫県立大学大学院 $\bar{T} 671-2280$ 姫路市書写 2167

Graduate School of Engineering, University of Hyogo, 2167 Shosha,

Himeji, Hyogo 671-2280, Japan.

**熊本高等専門学校 $\overline{7} 866-8501$ 八代市平山新町 2627

Kumamoto National College of Technology, 2627 Hirayama-shinmachi,

Yatsushiro, Kumamoto 866-8501, Japan.
管材の利用は有効とされている. 軽量かつ高剛性が重要視 される分野の構造材として期待されており，管材に関する 多くの研究が行われている，曲げ加工性に関しては，曲げ 加工性に及ぼすマンガン添加元素の影響について 9), 合金 管の冷間プレス曲げにおける変形挙動に及ぼす引張・圧縮 変形抵抗の影響について ${ }^{10)}$, 合金管のプレス曲げ加工性に 及ぼす温度の影響について ${ }^{11)}$, などの報告がある。また， 合金の材質を改善して塑性加工性を向上させる手法が数多 く報告されている．粉体技術による高強じん性合金の製造 技術の構築について ${ }^{12)}$, 強ひずみ变形による管材の結晶粒 微細化プロセスについて ${ }^{13)}$, などの報告がある. 一方, 著 者らも合金管の適用拡大のため, 軸圧縮を施した円管にお ける塑性座屈について調べている。これまでに, 塑性座屈 挙動における温度依存性と圧潰速度依存性について ${ }^{14)}$, ま た座屈応力に及ぼす管肉厚の影響について ${ }^{15)}$, などの報告 を行った。さらに，合金管の高強度化への手法としてショ ットピーニングを用い, 塑性座屈強度に及ぼす加工条件の 影響について調べ, 高強度化に対するショットピーニング の効果があることを報告した ${ }^{16)}$ 。このように合金管の塑性 加工性に関する研究は多く行われており，今後さらに利用 範囲を拡げるためには曲げ加工に関する知見が必要とされ ている.

本研究では構造材の強度向上という観点から, 既往研究 としてほとんど行われたことのない円管の曲げ加工性に及 
ぼすショットピーニングの影響について調べた。マグネシ ウム合金の中では比較的広く用いられている AZ31 合金管 を用い，投射条件の異なるショットピーニングの加工を施 した．引張および圧縮試験による機械的性質を調べるとと もに, 荷重付与時の曲げ強度に及ぼすショットピーニング の加工条件の影響について調べた。

\section{2. 実験方法}

供試材は，市販のマグネシウム合金 AZ31(Mg-3\%Al $-1 \% \mathrm{Zn}$ ) 円管押出材で, 外径 $D=\phi 22 \mathrm{~mm}$, 内径 $\phi 18 \mathrm{~mm}$, 肉厚 $2 \mathrm{~mm}$, 肉厚/平均直径比 0.1 , 平均硬さHV76 である. 種々 の加工条件下で管外表面にショットピーニングを施したの ち, 引張, 圧縮および曲げ試験に供した。 引張試験片は, 円管から平行部長さ $14 \mathrm{~mm}$, 幅 $3 \mathrm{~mm}$, 板厚 $2 \mathrm{~mm}$ で, 軸方 向が引張試験片の長手方向に一致するようにワイヤ放電加 工で切り出した. Fig. 1 に, 引張試験片の形状と寸法を示 す. 圧縮および曲げ試験片は, 円管から長さ $20 \mathrm{~mm}$ および $330 \mathrm{~mm}$ でそれぞれ切り出した形状で作製した。

Fig. 2 に，曲げ試験の構成を示す．圧縮試験は円管の軸 方向に対して平行に，また曲げ試験は円管の軸方向に対し て直角に負荷した(Fig. 2(a)). 曲げ試験において, 曲げ半径 $R=66 \mathrm{~mm}$ の治具を用い, 曲げ比 $(R / D)$ は 3 である(Fig. 2(b)). 曲げ試験での負荷は, クラック発生で生じる荷重の急激な 降下によって自動停止するまで行った。

引張, 圧縮および曲げ試験において, 精密万能試験機(島 津製作所製，負荷容量 $250 \mathrm{kN}$ )を用い，大気中，室温で行っ た。引張および圧縮試験におけるクロスヘッド速度は 10 $\mathrm{mm} / \mathrm{min}$ で，曲げ試験におけるそれは $100 \mathrm{~mm} / \mathrm{min}$ である.

ショットピーニングは主にインペラ式装置を用い, 試験 片外表面に対して加工を行った.一部の試験片に対しては, 空気式装置による加工を行った。 インペラ式装置による加 工では, 鋳鋼製 HV450, 平均直径 $1.0 \mathrm{~mm}$ の投射材を用い, 投射速度 $30 \sim 60 \mathrm{~m} / \mathrm{s}$ ，投射時間 $10 \sim 40 \mathrm{~s}$ ，投射面数 2 と 4 の加工条件である。空気式装置による加工では，鋳鋼製 HV450, 平均直径 $0.1 \mathrm{~mm}$ の投射材を用い, 噴射圧力 $0.6 \mathrm{MPa}$, 噴射時間 $20 \mathrm{~s}$ ，投射面数 4 の加工条件である。ここで，投 射面数とは, 円管を 180 度ずつ回転させて管全体を加工し た場合を面数 2, 円管を 90 度ずつ回転させて管全体を加工 した場合を面数 4 とした. Table 1 に, ショットピーニング を施した試験片の加工条件を示す.

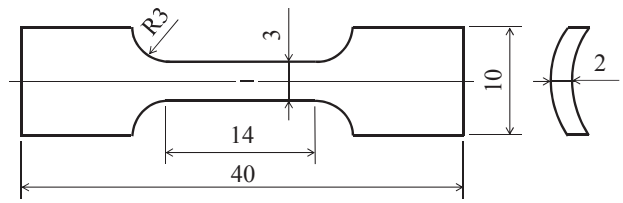

Fig. 1 Workpiece of tensile test (mm)
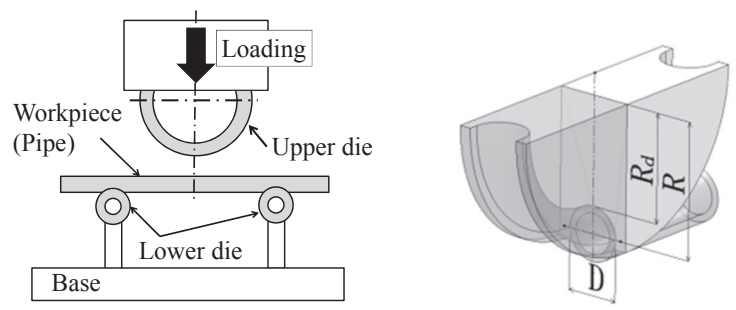

(a) Bending equipment (b) Parameters of upper die

Fig. 2 Schematic illustrations of bending test

\section{3. 応カーひずみ曲線}

\section{1 引張および圧縮試験}

円管の引張および圧縮における応力ーひずみ曲線に及ぼ すショットピーニングの影響について調べた。 引張試験の 場合，ショットピーニング加工を施した試験片（以後，加 工片と記す）における降伏応力は，加工を施していない試 験片 (以後, 未加工片と記す) のそれに比べて最大で約 $10 \%$ の増加が見られた. Fig. 3 に，加工片 Eにおいて得られた 公称引張および公称圧縮応力一公称ひずみ曲線を示す．図 中，ショットピーニングを施していない未加工片も比較と して示す。引張および圧縮試験の応力ーひずみ曲線におい て，加工片における応力は増加し，ひずみは減少している ことがわかる.ショットピーニングによって材料表面に加 工硬化層が形成されたためと考えられる。マイクロビッカ 一ス硬さ試験によって, 加工硬化層は表面から深さ約 $0.4 \mathrm{~mm}$ まで付与され, 表面層における最大硬さは約 HV120 で，加工前の硬さより約 HV44 の増加していることがわか った。また，圧縮試験から得られた応力ーひずみ曲線にお いて，ひずみの増加に伴う初期段階において下に凸になっ ている。この現象は, 双晶の出現に関わっていることが良 く知られている ${ }^{17)}$.

Table 1 Conditions of shot peening

\begin{tabular}{|c|c|c|c|c|c|}
\hline Workpiece & Shot size $/ \mathrm{mm}$ & $\begin{array}{l}\text { Peening } \\
\text { machine }\end{array}$ & $\begin{array}{c}\text { Impeller: Peening velocity } / \mathrm{m} \cdot \mathrm{s}^{-1} \\
\text { Air: Air pressure } / \mathrm{MPa}\end{array}$ & Peening time /s & $\begin{array}{c}\text { Number of peened } \\
\text { surface }\end{array}$ \\
\hline $\mathrm{A}$ & 1.0 & Impeller & 60 & 20 & 2 \\
\hline $\mathrm{B}$ & 1.0 & Impeller & 60 & 40 & 2 \\
\hline $\mathrm{C}$ & 1.0 & Impeller & 30 & 20 & 4 \\
\hline $\mathrm{D}$ & 1.0 & Impeller & 40 & 10 & 4 \\
\hline $\mathrm{E}$ & 1.0 & Impeller & 40 & 20 & 4 \\
\hline $\mathrm{F}$ & 1.0 & Impeller & 40 & 40 & 4 \\
\hline G & 1.0 & Impeller & 60 & 20 & 4 \\
\hline $\mathrm{H}$ & 0.1 & Air & 0.6 & 20 & 4 \\
\hline $\mathrm{I}(\mathrm{E}+\mathrm{H})$ & $1.0(\mathrm{E})+0.1(\mathrm{H})$ & $\begin{array}{l}\text { Impeller(E) } \\
+\operatorname{Air}(\mathrm{H})\end{array}$ & $40(\mathrm{E})+0.6(\mathrm{H})$ & $20(\mathrm{E})+20(\mathrm{H})$ & $4(\mathrm{E})+4(\mathrm{H})$ \\
\hline
\end{tabular}




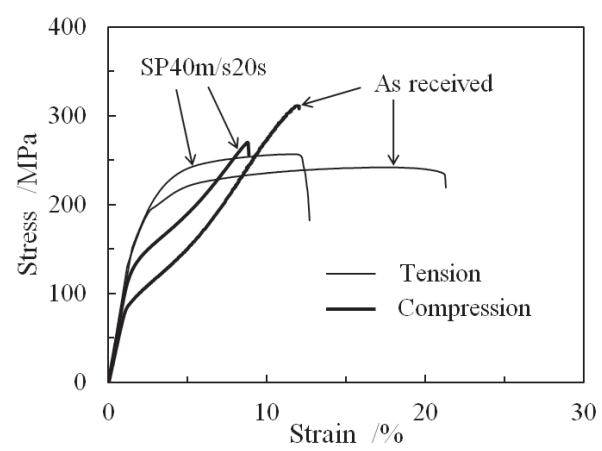

Fig. 3 Nominal tensile and compressive stress-strain curves of unpeened and shot-peened workpieces

Table 2 Mechanical properties of shot-peened workpieces

\begin{tabular}{|c|c|c|c|c|}
\hline Workpiece & $\sigma_{y t} / \mathrm{MPa}$ & $\Delta \sigma_{y t} / \%$ & $\sigma_{y c} / \mathrm{MPa}$ & $\Delta \sigma_{y c} / \%$ \\
\hline As received & 190 & 0 & 87.7 & 0 \\
\hline A & 190 & 0 & 127 & 44.8 \\
\hline B & 201 & 5.8 & 119 & 35.7 \\
\hline C & 210 & 10.5 & 130 & 48.2 \\
\hline D & 185 & -2.6 & 126 & 43.7 \\
\hline E & 201 & 5.8 & 129 & 47.1 \\
\hline F & 196 & 3.2 & 143 & 63.1 \\
\hline G & 205 & 7.9 & 159 & 81.3 \\
\hline H & 185 & -2.6 & 90 & 2.6 \\
\hline I (E+H) & 198 & 4.2 & 126 & 43.7 \\
\hline
\end{tabular}
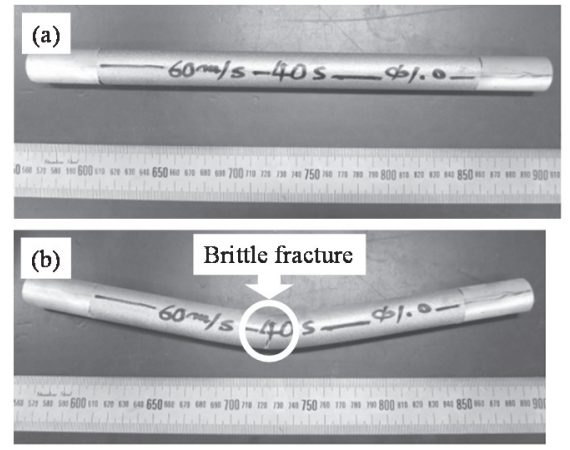

Fig. 4 Photos before and after bending test for a shot-peened pipe: (a) before bending and (b) after bending

Fig. 3 から得られた加工片の引張および圧縮降伏応力に おいて, 未加工片の降伏応力に対する変化率を求めた. 未 加工片の引張降伏応力 $\sigma_{y t}$ は $190 \mathrm{MPa}$, 圧縮降伏応力 $\sigma_{y c}$ は $87.7 \mathrm{MPa}$ であるのに対して, 加工片 $\mathrm{E}$ の $\sigma_{y t}$ は $201 \mathrm{MPa}, \sigma_{y c}$ は $129 \mathrm{MPa}$ と増加していた。 増加率にすると, 引張降伏応

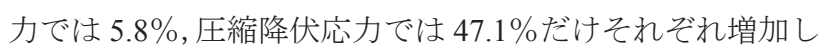
た.このように引張降伏応力の増加率よりも圧縮降伏応力 の増加率の方が大きい. この傾向は, 他のショットピーニ ング加工条件においても見られた.

Table 2 に, 未加工片と全ての加工片における公称引張お よび公称圧縮応力一公称ひずみ曲線から得られた引張降伏 応力 $\sigma_{y t}$, 引張降伏応力増加率 $\Delta \sigma_{y}$, 圧縮降伏応力 $\sigma_{y c}$, およ び圧縮降伏応力増加率 $\Delta \sigma_{y c}$ を示す. ここで, 引張および圧 縮降伏応力は $0.2 \%$ 残留ひずみ時の耐力 $\sigma_{0.2}$ で定義している.

\section{2 曲げ試験}

円管の曲げ強度に及ぼすショットピーニングの影響につ いて調べた。 ショットピーニングの加工条件は，円管への 投射面数，投射速度，投射時間および加工方式である. Fig. 4 に，ショットピーニングの加工条件 B で処理した曲げ試 験片における曲げ試験前後の試験片外観を示す。曲げ試験 後の管は曲げる途中において, クラックの発生によって脆 性破壊した。

円管の曲げ降伏荷重 $\left(P_{y}\right)$ に及ぼす投射面数の影響につい て調べた．Fig. 5 に，投射面数 2 である加工片 A と投射面 数 4 である加工片 $\mathrm{G}$ における曲げ荷重一変位曲線(a)および 曲げ降伏荷重一投射面数の関係(b)を示す．投射速度 $60 \mathrm{~m} / \mathrm{s}$ と投射時閒 $20 \mathrm{~s}$ の加工条件は同じである。ここで，曲げ降 伏荷重は単純支持梁の 3 点曲げ問題に対する実験条件入力 ウィザードにおいて, 0.2 \%残留ひずみ時の荷重として定義 している.まず，未加工材の曲げ降伏荷重 $\left(P_{y}=1.59 \mathrm{kN}\right)$ に比 べて, 加工片 Aおよび加工片 $\mathrm{G} の P_{y}$ は $2.26 \mathrm{kN}$ および $2.68 \mathrm{kN}$ で増加している。曲げ降伏荷重の増加率 $(\Delta P y)$ では，加工 片 A および加工片 $\mathrm{G}$ のそれは $42.1 \%$ および $68.6 \%$ の増加で あった，次に，曲げ荷重一変位曲線(a)において，投射面数 の違いによる变化が見られ，投射面数の増加につれて曲げ 荷重と曲げ降伏荷重も増加しているのがわかる。そこで, 曲げ降伏荷重一投射面数の関係(b)を見ると, 加工片 $\mathrm{G}$ の曲 げ降伏荷重 $\left(P_{y}\right)$ は加工片 A のそれに比べて約 1.2 倍増加し ている.このことから，円管に対して垂直方向に投射する 面数は 90 度ずつ回転させた 4 が曲げ降伏荷重 $\left(P_{y}\right)$ の向上に 有効であることがわかった。

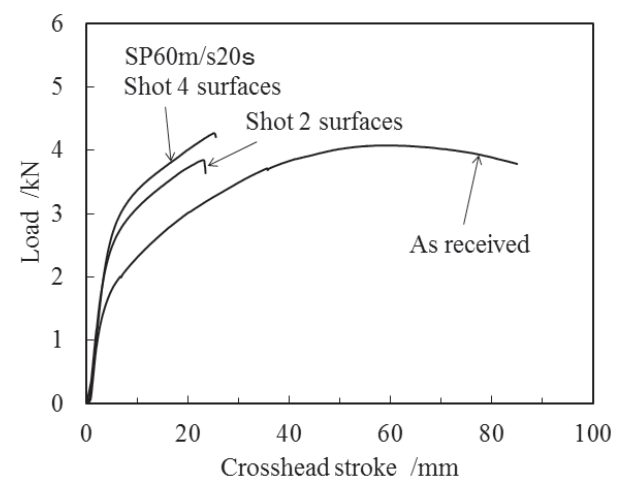

(a) Load-crosshead stroke curves

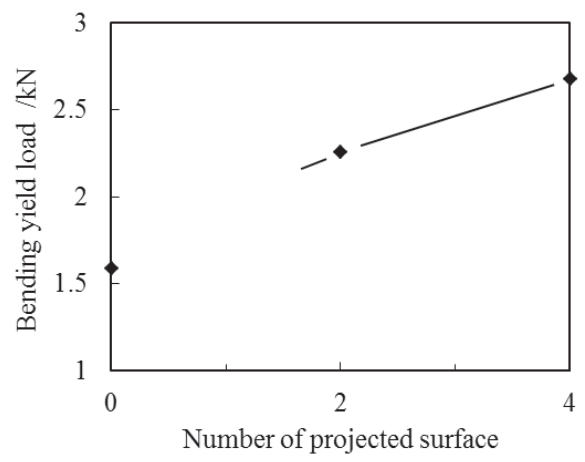

(b) Relationship between bending yield load and number of projected surface

Fig. 5 Effect of number of projected surface on bending yield load of AZ31 alloy pipe shot-peened with $60 \mathrm{~m} / \mathrm{s}$ and $20 \mathrm{~s}$ 
次に, 円管の曲げ降伏荷重 $\left(P_{y}\right)$ に及ぼす投射速度の影響 について調べた. Fig. 6 に, 投射速度 $30 \mathrm{~m} / \mathrm{s}$ である加工片 $\mathrm{C}, 40 \mathrm{~m} / \mathrm{s}$ の加工片 $\mathrm{E}$ および $60 \mathrm{~m} / \mathrm{s}$ の加工片 $\mathrm{G}$ における曲 げ荷重一変位曲線(a)および曲げ降伏荷重一投射速度の関 係(b)を示す. 投射時間 $20 \mathrm{~s}$ と投射面数 4 の加工条件は同じ である. 曲げ荷重一変位曲線(a)において, 投射速度の増加 につれて曲げ荷重と曲げ降伏荷重も増加しているのがわか る. 加工片 $\mathrm{C}, \mathrm{E}$ および $\mathrm{G} の P y$ はそれぞれ 2.11, 2.25 およ び $2.68 \mathrm{kN}$ である. 未加工片の $P_{y}(1.59 \mathrm{kN})$ に比べて増加し ており, 増加率はそれぞれ $32.7,41.5$ および $68.6 \%$ である. 曲げ降伏荷重一投射速度の関係(b)を見ると, 投射速度の増 加につれて $P_{y}$ は比例的に増加しているのがわかる.

次に，円管の曲げ降伏荷重 $\left(P_{y}\right)$ に及ぼす投射時間の影響 について調べた．Fig. 7 に，投射時間 10s の加工片 D, 20s の加工片 $\mathrm{E}$ および 40s の加工片 $\mathrm{F}$ における曲げ荷重一変位 曲線(a)および曲げ降伏荷重一投射時間の関係(b)を示す. 投 射速度 $40 \mathrm{~m} / \mathrm{s}$ と投射面数 4 の加工条件は同じである. 加工 片 D，Eおよび $\mathrm{F} の P_{y}$ はそれぞれ 2.15, 2.25 および $2.49 \mathrm{kN}$ である。投射時間の増加につれて， $P_{y}$ は増加しているのが わかる. また，未加工片の $P_{y}(1.59 \mathrm{kN})$ に比べて増加してお り，増加率はそれぞれ $35.2 ， 41.5$ および $56.6 \%$ である，以 上より，投射時間が長くなるにつれて，曲げ降伏荷重 $(P y)$ は増加することがわかった。

次に, 円管の曲げ降伏荷重 $\left(P_{y}\right)$ に及ぼす加工方式の影響 について調べた．Fig. 8 に，空気式で噴射圧力 $0.6 \mathrm{MPa}$ ，投 射時間 20s の加工片 H およびインペラ式と空気式を組み合 わせた加工片 I における曲げ荷重一変位曲線を示す。

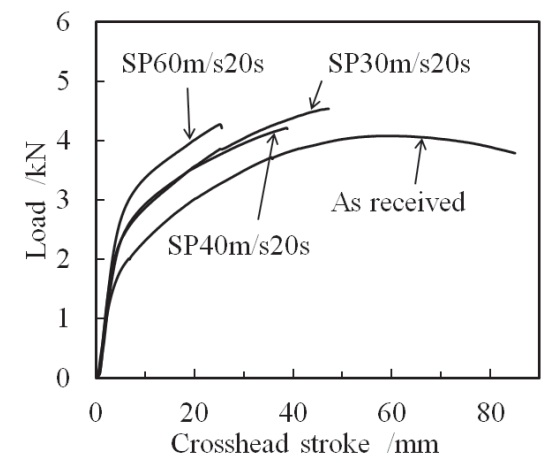

(a) Load-crosshead stroke curves

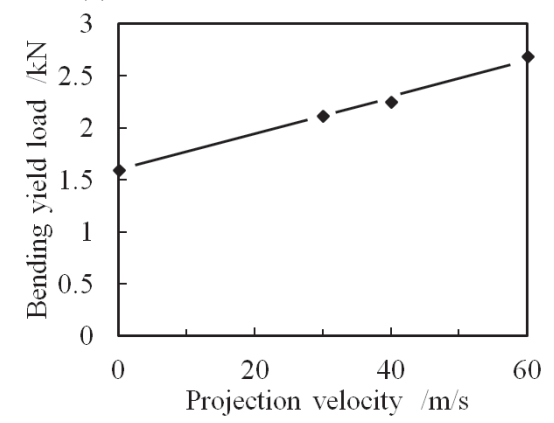

(b) Relationship between bending yield load and number of projected surface

Fig. 6 Effect of number of peening velocity on bending yield load of AZ31 alloy pipe shot-peened with $60 \mathrm{~m} / \mathrm{s}$ and $20 \mathrm{~s}$

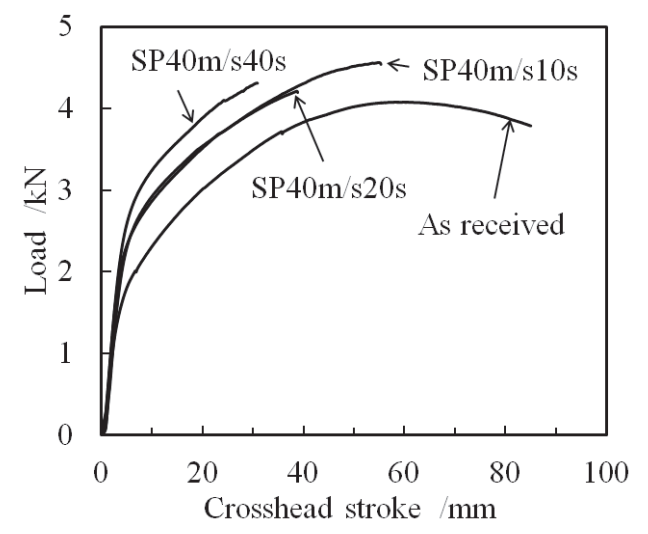

(a) Load-crosshead stroke curves

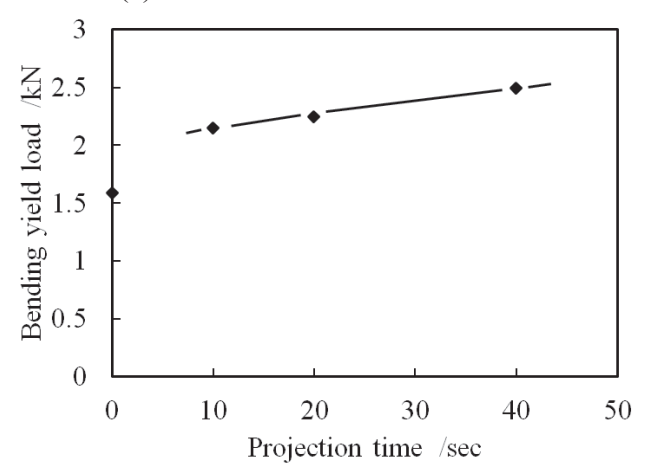

(b) Relationship between bending yield load and projection time

Fig. 7 Effect of peening time on bending yield load of AZ31 alloy pipe shot-peened with $40 \mathrm{~m} / \mathrm{s}$

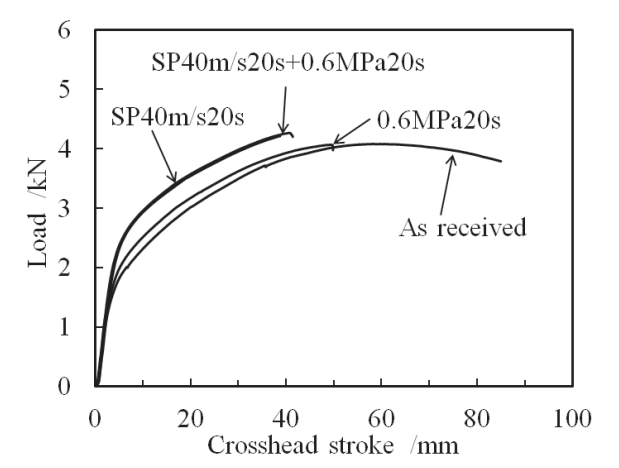

Fig. 8 Effect of processing method on bending yield load of AZ31 alloy pipe

比較として，未加工片およびインペラ式で投射速度 $40 \mathrm{~m} / \mathrm{s}$, 投射時間 $20 \mathrm{~s}$ の加工片 $\mathrm{E}$ における曲げ荷重一変位曲 線を併せて示す．空気式では，未加工の曲げ荷重と比べて 僅かに増加しているのが見られるが，インペラ式で加工し た加工片 $\mathrm{E}$ の曲げ荷重と比べてほとんど変化が見られない. 以上より，空気式のショットピーニングでは，円管の曲げ 荷重に及ぼす影響はほとんど見られないことがわかった。

Table 3 に, 未加工片と全ての加工片における曲げ試験か ら得られた曲げ降伏荷重 $P_{y}$, 曲げ降伏荷重増加率 $\Delta P_{y}$, 最

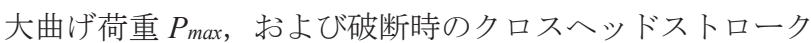
$\lambda_{f}$ を示す。ここで，破断時の $\lambda_{f}$ は負荷が自動的に停止する 時(曲げ荷重が円管表面からクラックの発生することにより 
Table 3 Mechanical properties of bent workpieces

\begin{tabular}{|c|c|c|c|c|}
\hline Workpiece & $P_{y} / \mathrm{kN}$ & $\Delta P_{y} / \%$ & $P_{\max } / \mathrm{kN}$ & $\lambda_{f} / \mathrm{mm}$ \\
\hline As received & 1.59 & 0 & 4.08 & $>90$ \\
\hline A & 2.26 & 42.1 & 3.85 & 22 \\
\hline B & 2.29 & 44.0 & 3.68 & 18 \\
\hline C & 2.11 & 32.7 & 4.53 & 47 \\
\hline D & 2.15 & 35.2 & 4.56 & 55 \\
\hline E & 2.25 & 41.5 & 4.21 & 38 \\
\hline F & 2.49 & 56.6 & 4.31 & 31 \\
\hline G & 2.68 & 68.6 & 4.27 & 26 \\
\hline H & 1.64 & 3.1 & 4.07 & 50 \\
\hline $\mathrm{I}(\mathrm{E}+\mathrm{H})$ & 2.27 & 42.8 & 4.26 & 41 \\
\hline
\end{tabular}

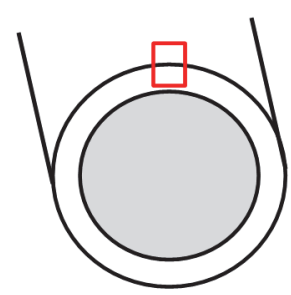

Surface

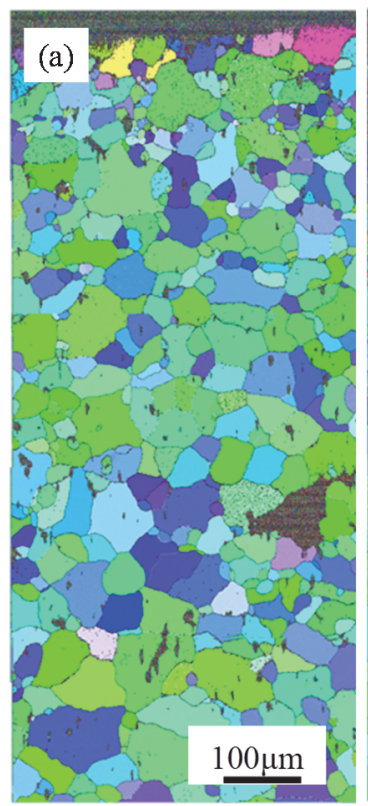

Fig. 9 IPF maps obtained on surface cross-section of as-received(a) and shot-peened workpiece E(b)
急激に減少する時)におけるストロークで定義した。曲げ降 伏荷重において, その増加率は圧縮試験で得られた圧縮降 伏応力の増加率(Table 2)に強く関係していることがわかる. しかし, 引張降伏応力の増加率(Table 2)にはあまり相関が 見られない. すべての加工条件において, 最も曲げ降伏荷 重が向上したのは加工片 $\mathrm{G}$ で，投射速度 $60 \mathrm{~m} / \mathrm{s}$, 投射時間 $20 \mathrm{~s}$ ，投射面数 4 の加工条件である.この条件下において, 曲げ降伏荷重 $P_{y}$ は未加工片 $1.59 \mathrm{kN}$ から $2.68 \mathrm{kN}$ と増加し, その増加率は $68.6 \%$ である。

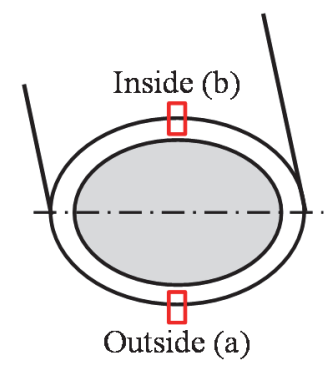

Orientation unit triangle

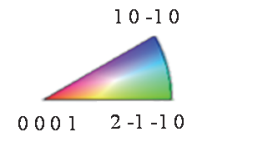

Surface
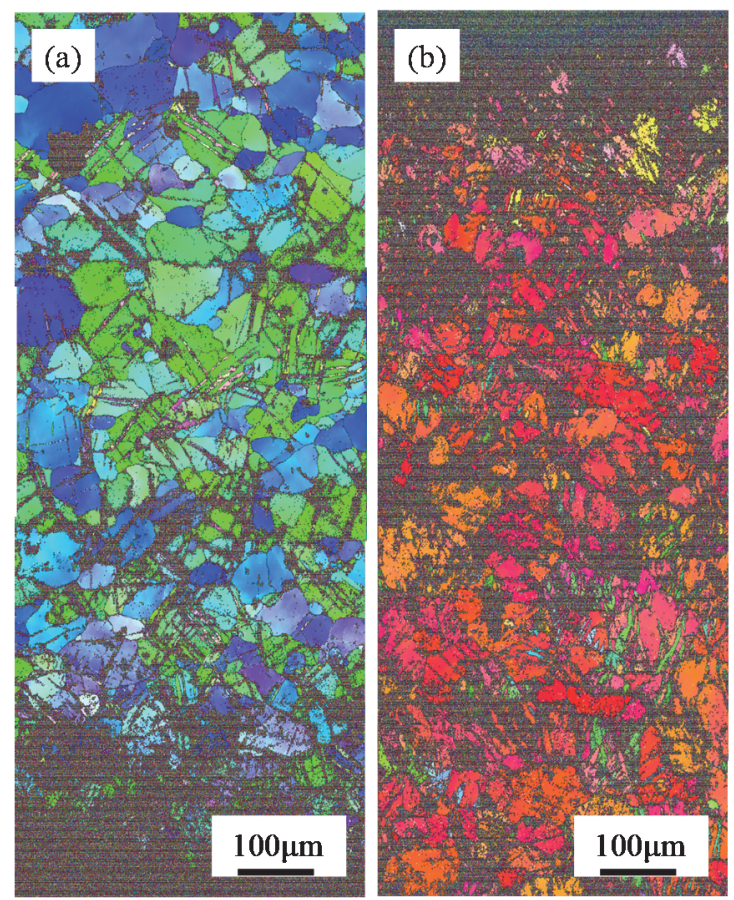

Surface

Fig. 11 IPF maps obtained on surface cross-section of outside(a) and inside(b) in bent peened pipe
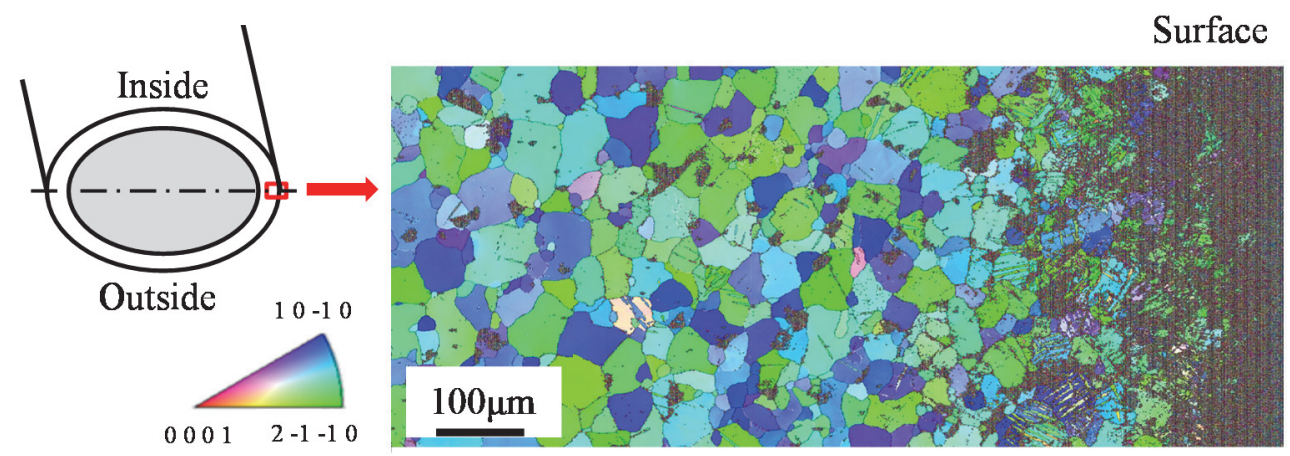

Fig. 10 IPF maps obtained on surface cross-section of middleside in bent peened pipe 


\section{4. 円管の組織}

一般に, 室温におけるマグネシウムの塑性加工は結晶構 造に起因して困難であることがよく知られている ${ }^{18)}$.これ は, 最密六方晶構造を有するマグネシウムは室温で活動可 能なすべり系が底面すべりに限定されるため, すなわちす べり系の数が極めて少ないためである ${ }^{19)}$.このようにすべ り系が少ないマグネシウムでは, 塑性変形時におけるす心゙ り系に影響を及ぼす双晶変形も無視できないことが知られ ている ${ }^{20)}$. 双晶が形成されると結晶方位が変わるため, そ れぞれのすべり系に作用する分解せん断応力も変化するの ですべり変形を誘起する可能性がある。これによって，マ グネシウム合金の塑性変形に双晶は大きな影響を与えると 考えられている21).

本研究においても前章でショットピーニングによる塑性 変形の付与によって円管の曲げ強度に及ぼす影響があるこ とがわかった。 とくに, 曲げ降伏荷重における増加率は圧 縮試験で得られた圧縮降伏応力の増加率に強く関係してい ることがわかった。 そこで, 本研究では加工片に対して曲 げ加工を行い, その際の変形挙動を結晶方位解析法(SEM / EBSD)によって組織観察を行った. SEM(Scanning Electron Microscope) は通常のタングステンフィラメント型の JSM-6360 で, EBSD(Electron Backscatter Diffraction Pattern) は TSL 製 MSC-2200, データ収集・解析ソフトは OIM ver.5.31 である.

\section{1 未加エ片と加エ片の組織}

Fig. 9 に, 円管の表面近傍断面における未加工片(a)およ び加工片 E(b)の IPF (Inverse Pole Figure) マップを示す. 結 晶方位と色調の関係は標準ステレオ三角形に示している通 りである.未加工片の場合，結晶粒は $0.02 \mathrm{~mm}$ から $0.1 \mathrm{~mm}$ とばらつきがあることがわかった。しかし，観察された結 晶面は柱面である(10-10) 面とそれに近い(2－1 - 1 0) 面で あった，圧延や押出しによって塑性加工された場合，底面 である(0001) 面が圧延や押出し方向に平行に配向された 強い底面集合組織を呈することに起因している ${ }^{22)}$. 次に, 加工片 $\mathrm{E}$ の場合, 表面近傍は結晶方向が観察できない黒い 領域が観察された.ショットピーニングによって表面層が 強加工されてひずみが蓄積されたものと考えられる.また, 強加工に伴う多くの双晶が生じていた。一方, 材料内部で は，柱面の結晶方位と近い(2-1 -1 0 ) 面において双晶が生 じており, 表面から深さ約 $1 \mathrm{~mm}$ においても観察された.

\section{2 曲げ加エした加エ片の組織}

ショットピーニングを施した加工片に対して, 曲げ加工 後の試験片における円管の側面, 内側および外側の三力所 の組織観察を行った. Fig. 10 に, 曲げ加工を行った加工片 E における円管の側面中央の表面近傍断面を示す．表面近 傍において, 曲げ加工前のショットピーニングで得られた 表面近傍の組織と比べると(Fig. 9), 導入された変形双晶は 減少しているのがわかる。一方, 材料内部において, 変形 双晶は完全に消滅しているのがわかる，著者の一人が圧縮 応力で生じた双晶に対して引張応力を負荷することで双晶 が消滅するという変形双晶の可逆性について報告した結果 と一致している ${ }^{23)}$. 本研究の場合, ショットピーニングに よって表層に付与された圧縮応力で変形双晶を生じたが,
側面付近の表面層では曲げ変形による円管の扁平で引張応 力状態となったためと考えられる.

Fig. 11 に，曲げ加工を行った加工片 E における円管の外 側(a)および内側(b)の表面近傍断面を示す. 円管の外側(a) の場合，柱面の結晶方位に近い(2-1 -1 0 $)$ 面において多く の変形双晶と思われる領域が見られ，その領域に多くのひ ずみが導入されて黒くなっている，マグネシウムの塑性変 形で生じる双晶は $\mathrm{c}$ 軸に対して引張応力状態となるときで あるため, 円管の外側では $\mathrm{c}$ 軸が圧縮される変形条件では 変形双晶は生じないことが知られている ${ }^{24)}$.このため, 結 晶方位の異なる双晶の領域においてひずみが蓄積したもの と考えられる. 次に, 円管の内側(b)の場合, 結晶方位が赤 色を示す底面である(0001) 面を呈している.さらに, 変形 双晶と思われる領域に多くのひずタが導入されて黒くなっ ている. 曲げ変形に伴う圧縮応力が負荷されて $\mathrm{c}$ 軸に対し て引張応力状態となったため, 変形双晶の領域でひずみの 蓄積が生じるとともに, 結晶全体が変形双晶を生じたもの と考えられる、マグネシウムの双晶面は（１０－－12）面である ことから, 曲げ変形前の柱面である(1 $0-10)$ 面と変形後の 底面である(0001)面の関係は垂直であることに起因する。 以上の結果から, 圧縮応力状態における変形双晶の挙動は 前章で述べた曲げ強度の増加率が圧縮降伏応力の増加率に 強く関係していることに対応していることがわかった。

\section{5. 結 言}

マグネシウム合金における構造材の強度向上という観点 から，円管の曲げ加工性に及ぼすショットピーニングの影 響について調べた。得られた知見は次の通りである。

（1）円管の曲げ強度は，投射面数，投射速度および投射時 間の増加につれて向上することがわかった。

(2) 曲げ強度に及ぼす加工方式において, 空気式よりもイ ンペラ式の方がより曲げ強度の向上に影響があること がわかった。

（3）曲げ強度の増加率は圧縮降伏応力の増加率に強く関係 していることがわかった。

（4）ショットピーニングによって表面層には変形双晶が生 じ，その双晶の領域には曲げ加工によってひずみが蓄 積されることがわかった。

(5) 組織観察によって, 曲げ強度の向上は変形双晶の形成 と深く関係があることがわかった。

最後に, 本研究を遂行するに際して, 本学大学院生の松 澤幸典氏の協力を得ました。ここに感謝の意を表します。 また，AZ31 マグネシウム合金円管を提供いただいた不二 ライトメタル（株）に厚く御礼申し上げます。

\section{参 考 文 献}

1) 金城和之・村山友巳・高橋功：東芝レビュー，68-6 (2013), 48-51.

2) 中島正貴 - 清水利弘 - 戸梶惠郎 - 植松美彦: 材料, 56-8 (2007), 764-771.

3) 楠川量啓・高尾健一:機械学会論文集 A, 68-671 (2002), 1092-1097.

4) 吉川高正・稲葉忠司・橋本結衣・横尾優哉・徳田正孝 : 材料, 62-5 (2013), 311-318. 
5) 三浦博已 - 劉恒哲 : 軽金属, 61-10 (2011), 518-524.

6) 藤井敏男 - 山本元道・篠崎賢二 : 軽金属, 63-6 (2013), 223-228.

7) 野田雅史 - 酒井直人 - 船見国男 - 森久史 - 藤野謙司 : 塑性と加工，54-625 (2013)， 143-147.

8) King, J.F., Lyon, P. \& Savage, K.: マグネシウム，31-12 (2002), 1-9.

9) 須貝純一 - 岩井匡之 - 本保元次郎 - 清水亨 - 早田博 アレキサンダー マクリーン: 軽金属, 56-12 (2006), 705-710.

10) 長谷川収・真鍋健一・西村尚：塑性と加工， 47-540 (2006), 59-63.

11) 長谷川収・真鍋健一・井上直人・西村尚: 塑性と加工, 48-556 (2007), 422-426.

12）金子貫太郎・塩崎修司・護法良憲・秋田亭・近藤勝義・ 荻沼秀樹：塑性と加工，47-551 (2006), 1187-1190.

13) 古島剛 - 真鍋健一 - 清水徹英 : 塑性と加工, 48-556 (2007), 412-416.

14) 福田泉 - 大石保生 - 村井勉 : 第 55 回塑性加工連合講 演会講演論文集，(2004)，127-128。
15) 福田泉 - 田中裕一 - 村井勉 : 第 56 回塑性加工連合講 演会講演論文集，(2005), 127-128.

16) 福田泉 - 田中裕一 - 原田泰典 : 塑性と加工, 50-576 (2009), 59-63.

17) Wu, L., Jain, A., Brown, D.W., Stoica, G.M., Agnew, S.R., Clausen, B., Fielden, D.E. \& Liaw, P.K. : Acta Mater., 56-4 (2008), 688-695.

18）日本マグネシウム協会編: 現場で生か寸金属材料シリ ーズ マグネシウム, (2009), 20-22, 丸善出版.

19）吉永日出男：金属物理, 10-3 (1963), 91-100.

20) 日本塑性加工学会編：マグネシウム加工技術, (2004), 12-13, コロナ社.

21）浄徳昌宏・山本厚之・椿野晴繁: 軽金属, 56-12 (2006), 711-715.

22) 村上雄 : 軽金属, 52-11 (2002), 536-540.

23) Uota, T., Suzu, T., Fukumoto, S. \& Yamamoto, A. : Mater. Trans., 50-8 (2009), 2118-2120.

24) Edington, J.W., Melton, K.N. \& Cutler, C.P. : Prog. in Mater. Sci., 21 (1976), 61-66. 